\title{
Efektifitas Smartbook Perawatan Paska Seksio bagi Kualitas Pelayanan Keperawatan
}

\author{
Lisa Kausar ${ }^{1}$ Fitarina $^{2}$, Sono ${ }^{3}$ \\ 1,2,3 Jurusan Keperawatan, Politeknik Kesehatan Tanjungkarang, Indonesia \\ Email: lisakausar@yahoo.co.id
}

\begin{abstract}
Qualitative Analysis of Nursing Services Using The Smartbook of Post-Section Care. There are 5 highest causes of maternal mortality which include bleeding, hypertension in pregnancy, infection, prolonged labor, and abortion. One of the prevention and management efforts is to provide immediate and efficient help through hospital services (Ministry of Health, 2014). This research has aims to find the quality of nursing services on patients after cesarean surgery using the SmartBook. Methods: This is Quasi-Experiment that provides treatment with the SmartBook for 4 days in the hospital and assessed nursing services quality. Samples were taken using accidental and random sampling (20 for the intervention group and 21 for the control group). Data was collected using observation sheet and questionnaire, then analyzed with a t-test. Result: There are four variables of nursing service quality ( $\mathrm{p}$-value $<0.05$ ) indicating significant difference: patient safety, self-care, anxiety, and knowledge of discharge planning, while 2 others (comfort and satisfaction) are not ( $p$-value>0.05). Application of the SmartBook for women following cesarean surgery improves nursing service quality. We suggest further research on nurse and midwife perception about the use of the SmartBook as media of care, both about its use and how far can improve job satisfaction of nurse/midwife.
\end{abstract}

Keywords: Nursing services quality, Smartbook, Caesarean surgery

\begin{abstract}
Abstrak: Analisis Kualitas Pelayanan Keperawatan dengan Menggunakan Smartbook Perawatan Paska Seksio. Terdapat 5 penyebab tertinggi kematian ibu bersalin yang meliputi perdarahan, hipertenesi dalam kehamilan, infeksi, partus lama, dan aborsi. Salah satu upaya pencegahan dan penatalaksaan adalah dengan diberikannya pertolongan segera dan efisien melalui pelayanan di rumah sakit (Kemenkes, 2014). Tujuan penelitian untuk mengetahui mutu pelayanan keperawatan pasien pasca sectio dengan menggunakan Smartbook perawatan pasca seksio. Metode: Design penelitian adalah Quasi Eksperimen yaitu memberikan perawatan dengan media kontrol dan pendidikan pasien berupa Smartbook perawatan pasca sectio untuk perawatan selama 4 hari di Rumah Sakit, Sampel: sampel penelitian ini diambil dengan accidental sampling dan sistematica random sampling sampel 20 untuk kelompok intervensi dan 21 untuk kelompok kontrol. Pengambilan data menggunakan lembar observasi dan kuisioner. Analisis statistik menggunakan $t$ test. Hasil Penelitian: terdapat empat variabel mutu pelayanan keperawatan dengan nilai $p$-value $<0.05$, ini berarti ada perbedaan yang signifikan mean skor empat varibel kinerja yaitu: keselamatan pasien, perawatan diri, kecemasan dan pengetahuan discharge planning, sedangkan 2 variabel kinerja (kenyamanan dan kepuasan) dengan nilai $p$-value $>0.05$. Aplikasi Smartbook untuk wanita setelah bedah caesarea meningkatkan kualitas layanan keperawatan. Penelitian ini merekomendasikan Penggunaan Smartbook pada perawatan pasien seksio sesarea untuk mengontrol dan memfasilitasi selfcare empat variabel yang signifikan dan pentingnya penelitian lebih lanjut tentang penggunaan Smartbook bagi kepuasan perawat/bidan.
\end{abstract}

Kata kunci: Kualitas layanan Keperawatan, Smartbook, Seksio sesarea

Penatalaksanaan masalah kesehatan pada ibu dan anak sampai pada saat ini masih menjadi prioritas penanganan masalah untuk diatasi. Hal tersebut sebagaimana tergambar dalam data yang menunjukkan bahwa target penurunan angka kematian ibu dan bayi di Indonesia yang masih tinggi (19 per 1000 kelahiran) (Kemenkes, 2015). Terdapat 5 penyebab tertinggi kematian ibu bersalin yang meliputi perdarahan, hipertenesi dalam kehamilan, infeksi, partus lama, dan aborsi. Diperkirakan sebanyak 20\% kehamilan akan mengalami komplikasi. Sebagian komplikasi yang muncul dalam kehamilan dapat bersifat mengancam nyawa, tetapi sebagian komplikasi lainnya dapat dilakukan pencegahan dan penatalaksanaan. Salah satu upaya pencegahan 
dan penatalaksaan adalah dengan diberikannya pertolongan segera dan efisien melalui pelayanan di rumah sakit (Kemenkes, 2014).

Tindakan medis yang paling sering dilakukan bagi wanita hamil di rumah sakit adalah tindakan operasi cesar $(40 \%$ dari seluruh kunjungan ibu hamil) (Rekam Medik Ruang Maternitas RSUD Mayjend HM. Ryacudu, 2017). Kebutuhan ibu pasca operasi sesar meliputi kebutuhan rasa nyaman (bebas dari nyeri), kebutuhan mobilisasi, dan kebutuhan untuk menyusui bayinya (Suarni L, \& Nurjanah I, 2016). Latihan nafas dalam, mobilisasi, perawatan luka, fasilitasi menyusui, dan rencana pemulangan sangatlah penting dan wajib dilakukan pad ibu pasca operasi sesar (Rahayu R, \& Andriyani A, 2014, Setyawati L, Ariyanti I, Wahyuni S, 2013, Puspitasari1. HA., Basirun-, Sumarsih T, 2011, Pratiwi R, 2012). Perawat memiliki tanggung jawab untuk melakukan seluruh tindakan tersebut pada ibu yang sedang menjalani masa pemulihan dari operasi sesar. Fakta di lapangan menunjukkan bahwa asuhan yang diberikan pada ibu-ibu tersebut tidak selalu efektif yang berdampak pada rendahnya kualitas layanan asuhan keperawatan. (Suarni L, 2016).

Tindakan keperawatan untuk pemenuhan kebutuhan ibu selama pemulihan pasca operasi sesar merupakan hal yang wajib dilakukan. Oleh karena itu, sangatlah perlu dibuat sebuah desain model asuhan keperawatan khusus bagi ibu pasca operasi sesar yang melibatkan ibu secara aktif dengan tujuan meningkatkan efektivitas asuhan keperawatan yang pada akhirnya dapat meningkatkan kualitas asuhan keperawatan.

Untuk dapat menerapkan model konseptual dan teori defisit perawatan diri Orem pada ibu pasca seksio sesarea diperlukan standar asuhan berupa panduan atau media yang dapat dipergunakan oleh pasien dan perawat atau bidan selama pemantauan pemulihan ibu paska seksio sesarea. Pada penelitian ini digunakan sebuah panduan dalam bentuk buku. Buku berfungsi untuk mengoptimalkan peran ibu dalam perawatan dirinya pasca oeprasi sesar. Buku berjudul "Smart book (Smartbook) Perawatan paska Seksio Sesarea". Penelitian ini untuk membuktikan apakah buku tersebut efektif untuk meningkatkan kualitas asuhan keperawatan pada ibu pasca seksio cesarean. Tujuan penelitian ini adalah untuk mengetahui efektifitas Smartbook perawatan paska Seksio Sesarea bagi kualitas pelayanan keperawatan .

\section{METODE}

Populasi penelitian ini adalah ibu-ibu paska seksio sesarea, Sampel penelitian berjumlah 41 yang diperoleh melalui teknik accidental sampling dengan 20 responden dikelompokkan dalam kelompok intervensi dan 21 responden dalam kelompok kontrol. Sampel dipilih dengan system acak dimana pasien yang pertama datang dikelompokkan dalam kelompok diintervensi, pasien ke dua dalam kelompok kontrol, dan seterusnya hingga pasien terakhir. Kriteria inklusi dalam penelitian ini adalah pasien mampu membaca dan menulis, dan menandatangani persetujuan responden.

Penelitian ini dilakukan sesuai dengan prinsip-prinsip etik, telah disetujui oleh Komite Etik Poltekkes Tanjungkarang sebagai penelitian non klinik. Responden telah mendapatkan penjelasan sebelum mereka dilibatkan dalam penelitian ini, jika mereka bersedia menjadi responden maka diminta menandatangani informed consent. Responden diperkenankan berhenti terlibat jika responden memutuskan untuk berhenti menjadi responden ketika sedang dalam proses penelitian.

Pasca operasi sesar, ibu dipindahkan ke ruang rawat kebidanan. Setelah di ruang rawat kebidanan, ibu dalam kelompok intervensi diberikan Smartbook dan dijelaskan hingga paham tentang cara penggunaanya dan mau menggunakan buku tersebut. Ibu dalam kelompok kontrol tidak diberikan Smartbook dan penjelasan, hanya mendapatkan asuhan keperawtan rutin. Pada hari ke-4 dilakukan evaluasi apakah seluruh bagian dalam Smartbook telah diisi dengan diberikan tanda sesuai petunjuk pengisian atau tidak. Buku yang tidak disi dengan lengkap dianggap sebagai tidak dilaksanakan. Perawat penanggung jawab kemudian mengevaluasi kualitas asuhan keperawatan menggunakan kuisioner yang disusun oleh peneliti dan sudah diuji validitasnya selanjutnya dibagikan kepada pasien untuk diisi. Evaluasi dilakukan untuk mengkaji kenyamanan, kepuasan, kecemasan, dan pengetahuan akan perencanaan pemulangan, sedangkan keamanan dan perawatan diri dikaji menggunakan formulir observasi.

Untuk mengetahui kepuasan pasien dilakukan analisa data dengan mengunakan uji $\mathrm{t}$ untuk membandingkan kepuasan pasien antara kelompok kontrol dan kelompok intervensi. Setiap sub variable dependent diberikan skor. Hal ini berarti bahwa skor dengan nilai tinggi berarti baik, sedangkan skor rendah berarti buruk. 
HASIL

Tabel 1. Karakteristik Responden

\begin{tabular}{lrr}
\hline \multicolumn{1}{c}{ Variabel } & n & \multicolumn{1}{c}{$\%$} \\
\hline Usia & & \\
$<20$ tahun & 3 & 7.3 \\
$20-35$ tahun & 29 & 70.7 \\
$>35$ years & 9 & 22 \\
Paritas & & \\
$\quad$ Primigravida & 11 & 26.8 \\
Multigravida & 29 & 70.7 \\
Grandemulti & 1 & 2.5 \\
Faktor Penyebab & & \\
Riwayat Cesar & 5 & 12.1 \\
Panggul sempit & 4 & 9.7 \\
Kelainan letak & 14 & 34.1 \\
Placenta previa & 3 & 7.4 \\
Hemorrhoid & 2 & 4.9 \\
Gemeli & 3 & 7.4 \\
Pre-eklampsi & 2 & 4.9 \\
Ketuban pecah dini & 3 & 7.4 \\
Lainnya & 5 & 12.1 \\
\hline
\end{tabular}

Tabel 2. Kualitas Asuhan Keperawatan pada Ibu Pasca Sectio Cesarea dengan menggunakan Smartbook Perawatan Post Seksio

\begin{tabular}{lccccc}
\multicolumn{1}{c}{ Variabel } & Mean & SD & SE & $\begin{array}{c}p \text { - } \\
\text { value }\end{array}$ & $\mathbf{n}$ \\
\hline $\begin{array}{l}\text { Keselamatan pasien } \\
\text { Kelompok } \\
\text { intervensi }\end{array}$ & 17.4 & 0.75 & 0.17 & & 20 \\
$\begin{array}{l}\text { Kelompok } \\
\text { control }\end{array}$ & 16.1 & 1.26 & 0.28 & 0.00 & 21 \\
\hline $\begin{array}{l}\text { Perawatan diri } \\
\text { Kelompok } \\
\text { intervensi }\end{array}$ & 32.75 & 5.7 & 1.3 & 0.01 & 20 \\
$\begin{array}{l}\text { Kelompok } \\
\text { kontrol }\end{array}$ & 26.05 & 5.8 & 1.3 & & 21 \\
\hline $\begin{array}{l}\text { Kualitas asuhan keperawatan } \\
\text { Kelompok } \\
\text { intervensi }\end{array}$ & 1.55 & 1.85 & 0.41 & 0.6 & 20 \\
$\begin{array}{l}\text { Kelompok } \\
\text { kontrol }\end{array}$ & 1.38 & 1.47 & 0.32 & & 21 \\
\hline $\begin{array}{l}\text { Kenyamanan } \\
\text { Kelompok } \\
\text { intervensi }\end{array}$ & 1.55 & 1.85 & 0.41 & 0.6 & 20 \\
$\begin{array}{l}\text { Kelompok } \\
\text { kontrol }\end{array}$ & 1.38 & 1.47 & 0.32 & & 21 \\
\hline $\begin{array}{l}\text { Kecemasan } \\
\text { Kelompok } \\
\text { intervensi }\end{array}$ & 1.75 & 0.44 & 0,09 & 0.02 & 20 \\
$\begin{array}{l}\text { Kelompok } \\
\text { kontrol }\end{array}$ & 2,29 & 0.56 & 0.12 & & 21 \\
\hline $\begin{array}{l}\text { Pengetahuan rencana pulang } \\
\text { Kelompok } \\
\text { intervensi }\end{array}$ & 166.05 & 57.8 & 12.93 & 0.02 & 20 \\
$\begin{array}{l}\text { Kelompok } \\
\text { kontrol }\end{array}$ & 121.19 & 21.84 & 4.77 & & 21 \\
\hline $\begin{array}{l}\text { Skor total kualitas asuhan keperawatan } \\
\text { Kelompok } \\
\text { intervensi }\end{array}$ & 241.40 & 60.0 & 13.4 & 0.04 & 20 \\
$\begin{array}{l}\text { Kelompok } \\
\text { kontrol }\end{array}$ & 198.52 & 23.20 & 5.06 & & 21 \\
\hline & & & & & \\
\hline
\end{tabular}

\section{PEMBAHASAN}

Mutu layanan keperawatan yang ditinjau dari enam aspek yaitu keamanan, kenyamanan, kecemasan, perawatan dan discharge planning (perencanaan pulang). Hasil analisis pada penelitian ini menunjukkan dari ke enam aspek tersebut empat aspek menunjukkan ada perbedaan skor signifikan antara perawatan dengan menggunakan Smartbook dengan yang tidak menggunakan Smartbook yaitu: keselamatan, perawatan diri, kecemasan, dan pengetahuan perencanaan pulang. Dimana perawatan dengan menggunakan Smartbook ke empat aspek tersebut lebih baik dibanding dengan yang tidak menggunakan Smartbook.

Smartbook adalah media yang berisikan gambar dan penjelasan, yang memungkinkan pasien mendapatkan informasi tentang perawatan pasaca SC. Media ini adalah media visual, 
menurut Maulana (2009) panca indera yang banyak menyalurkan pengetahuan ke otak adalah mata (kurang lebih $75 \%$ sampai $87 \%$ ), sedangkan $13 \%$ sampai $25 \%$, pengetahuan manusia diperoleh dan disalurkan melalui pancaindera yang lain. Penelitian Kapti. R.E., Rustina. Y., Widyatuti, (2013) juga membuktikan bahwa pendidikan kesehatan dengan menggunakan media audiovisual efektif sebagai media penyuluhan.

Penelitian Supardi. S.,Sampurno.O.D., Siswoyo, M., (2002), menyatakan bahwa pasien yang diberi penyuluhan dengan menggunakan media lieflet efektif terhadap perubahan perilaku selfcare (pemberian obat sendiri). Tidak dapat dipungkiri bahwa perilaku pasien, menjaga keselamatan, melakukan perawatan diri sangat erat kaitannya dengan pengetahuan yang dimiliki. Adanya media Smartbook adalah memberikan sejumlah pengetahuan tentang bagaimana perawatan pasien pasca seksio, dimana perawatan.

Beberapa Penelitian yang menggambarkan pentingnya selfcare dipahami oleh perawat serta bagimana mengoptimalkan selfcare pada pasien melalui pendidikan kesehatan dengan menggunakan beberapa media diantaranya media buku, leaflet, Booklet, dll (Crane, P.J., Ward.S.F., 2010, Rantung.J., Yetti.K., Herawati. T., 2015., Indanah, Yetti.K., Sabri.L., 2012).

Hasil analisis skor keselamatan, perawatan diri, kecemasan dan pengetahuan yang menunjukkan perbedaan sifgnifikan (skor tinggi/baik ) pada pasien yang menggunakan Smartbook, hal dapat dimengerti dan sesuai dengan penelitian yang dilakukan Sistiarani, dkk yang meneliti tentang pemanfaatan Buku KIA, didapatkan kesimpulan bahwa ada hubungan yang bermakna antara fungsi pencatatan dengan pengetahuan KIA (Sistiarani.C., Gamelia.E., Sari.D.U.P., 2014).

Faktor keselamatan, untuk menilai faktor keselamatan pasien indikator penilaiannya adalah frekuensi kejadian dekubitus, pasien jatuh, flebitis dan kesalahan pengobatan. Hasil analisis skor keselamatan responden yang dinilai dari Kejadian dekubitus, kejadian flebitis, kejadian pasien jatuh dan keselahan pengobatan. Analisis $t$ test menunjukkan bahwa ada perbedaan signifikan antara skor keselamatan pasien dengan penggunaan Smartbook keperawatan dengan yang tidak, Smartbook merupakan media pendidikan termasuk pendidikan tentang keselamatan pasien.

Pasien post sc adalah pasien dengan kategori Partly Compensatory System (Orem, D.E., 1991) artinya dengan Smartbook yang berisikan kontrol pasien terhadap perawatan yang dilakukan oleh perawat dan pengetahuan tentang apa yang dapat dilakukan ataupun tidak dapat dilakukan oleh pasien akan memperkecil risiko terjadinya gangguan keselamatan pada pasien. Hasil penelitian ini menunjukkan adanya perbedaan skor kemampuan merawat diri sehari-hari (Activity Daily Living), pengetahuan dan kecemasan antara pasien yang menggunakan Smartbook dengan yang tidak menggunakan, hal ini dapat dijelaskan bahwa pengetahuan, kecemasan dan Perawatan diri adalah hal yang saling berhubungan, dimana semakin tinggi pengetahuan, maka akan meningkatkan kemampuan memenuhi kebutuhan dasar sehari-hari, demikian juga dengan pengetahuan akan menurunkan tingkat kecemasan yang selanjutnya dapat meningkatkan kemampuan pasien untuk melakukan perawatan diri sehari-hari (ADL) (Ratnasari P, dkk., 2012).

Hasil analisis Pengetahuan persiapan pulang (Discharge Planing) menunjukkan bahwa ada perbedaan yang signifikan antara responden yang menggunakan Smartbook dengan yang tidak menggunakan, Smartbook adalah media pendidikan kesehatan yang berisi informasi tentang beberapa hal diataranya persiapan pulang (discharge planning). Media ini cukup efektif sesuai dengan penelitian Supardi. S., Sampurno.O.D., Siswoyo, M., (2002), menyatakan bahwa pasien yang diberi penyuluhan dengan menggunakan media leaflet efektif terhadap perubahan perilaku selfcare (pemberian obat sendiri).

Hasil analisis pada penelitian ini menunjukkan bahwa terdapat dua variabel yang tidak memperlihatkan perbedaan ( $p$-value $>0,5)$ antara responden yang menggunakan Smartbook dengan yang tidak menggunakan, yaitu Kenyamanan dan Kepuasan pasien. Pengetahuan adalah aspek yang penting dalam dimensi kognitif. Pengetahuan tentang nyeri dan penanganannya dapat mempengaruhi respon seseorang terhadap nyeri dan penanganannya. Nyeri itu sendiri dapat dimodifikasi oleh bagaimana seseorang berpikir tentang nyeri yang dirasakannya, apa saja pengharapannya atas nyerinya, dan apa makna nyeri tersebut dalam kehidupannya (Ahles et al, 1983, Barkwell (2005) dalam Ardinata.D, 2007). Pengetahuan yang dimaksud adalah pengetahuan masa lampau tentang nyeri menyangkut pengaruh nyeri yang dirasakan oleh individu terhadap proses berpikirnya atau pandangan individu terhadap dirinya sendiri. Hal ini tidak terkait informasi yang didapatkannya melalui Smartbook. 


\section{SIMPULAN}

Penggunaan Smartbook Perawatan Post-SC pada asuhan keperawatan pada pasien pasca SC menunjukkan kualitas asuhan keperawatan yang lebih baik. Kesimpulan ini didasarkan pada hasil yang menunjukkan bahwa terdapat perbedaan yang bermakna dalam keselamatan pasien, kemampuan perawatan diri pasien, kecemasan pasien, pengetahuan akan perencanaan pulang, dan kualitas pelayanan asuhan keperawatan antara kelompok yang menggunakan Smartbook Perawatan Post-SC dengan yang tidak menggunakan Smartbook Perawatan Post-SC, meskipun dua skor variabel lainya tidak menunjukkan adanya perbedaan yang bermakna.

\section{DAFTAR PUSTAKA}

Ardinata, D. 2007. Multidimensional Nyeri. Jurnal Keperawatan Rufaidah Sumatera Utara, Volume 2 Nomor 2, November 2007.

Crane, P. J., \& Ward, S. F. 2016. Self-healing and self-care for nurses. AORN journal, 104(5), 386-400. www.aornjournal.org/content/cme

Indanah, Yetti.K., Sabri. L. 2012. Dukungan Sosial Meningkatkan Selfcare Behavior Anak Vol 1, No 2 (2013): Jurnal Keperawatan Anak.

Kapti. R.E., Rustina. Y., Widyatuti, 2013., Efektifitas Audiovisual sebagai Media Penyuluhan Kesehatan terhadap Peningkatan Pengetahuan dan Sikap Ibu dalam Tatalaksana Balita dengan Diare di Rumah Sakit Kota Malang. Jurnal Ilmu Keperawatan. Volume 1, No. 1.

Kementerian Kesehatan RI. 2015. Panduan Perencanaan Kesehatan. Jakarta: Kementerian Kesehatan RI.

Kementerian Kesehatan RI. 2014. Statistik Kesehatan, Jakarta: Kementerian Kesehatan RI.

Maulana, H. 2009. Promosi Kesehatan. Jakarta: EGC.

Orem, DE. 1991. Nursing Concept of Practice. The C.V. Mosby Company. St Louis.

Pratiwi, R. 2012. Penurunan Intensitas Nyeri Akibat Luka Post Sectio Caesarea Setelah Dilakukan Latihan Teknik Relaksasi Pernapasan Menggunakan Aromaterapi Lavender di Rumah Sakit Al Islam Bandung. Students e-Journal, 1(1), 30.

Puspitasari1. HA., Basirun-, Sumarsih T, Faktor-faktor yang mempengaruhi Penyembuhan luka Post Operasi Seksio

\section{SARAN}

Berdasarkan hasil penelitian ini, perawat dan bidan disarankan menggunakan Smartbook Perawatan Post-SC dalam memberikan pelayanan asuhan keperawatan untuk mengoptimalkan asuhan keperawatan pada pasien post-SC. Penelitian ini merekomendasikan penelitian lebih lanjut persepsi perawat/bidan tentang penggunaan Smartbook Perawatan Post-SC sebagai media perawatan, baik tentang penggunaanya maupun seberapa jauh dapat meningkatkan kepuasan kerja perawat/bidan.

Caessarea (SC). Jurnal Ilmu Kesehatan, Vol 7, No 1 2011. http://www. ejournal.stikesmuhgombong.ac.id/index.ph $\mathrm{p} / \mathrm{JIKK} /$ article/view/25.

Rahayu R, \& Andriyani A, Metode memperbanyak Produksi ASI Pada Ibu Post Seksio dengan Teknik Marmet dan Breascare di RSUD Karanganyar. Gaster Jurnal Ilmu Kesehatan, Vol 11, No 2, 2014. http://www.jurnal.stikes-aisyiyah. ac.id/index.php/gaster/article/view/78

Rantung.J., Yetti.K., Herawati. T. 2015. Hubungan Selfcare dengan Kualitas Hidup Pasien Diabetes Melitus di PERSADIA cabang Cimahi. Jurnal Skolastik Keperawatan, Vol.1, No. 1.

Ratnasari, P., Kristiyawati, S. P., \& Solechan, A. 2012. Hubungan antara tingkat ketergantungan activity daily living dengan depresi pada pasien stroke di RSUD Tugurejo Semarang. Karya Ilmiah S. 1 Ilmu Keperawatan.

e-journal/index.php/ilmukeperawatan/article /view/70/107

RSUD Mayjend HM. Ryacudu. 2017. Rekam Medik Ruang Maternitas RSUD Mayjend HM. Ryacudu. Tidak dipublikasikan.

Sistiarani. C., Gamelia. E., Sari. D. U. P. 2014. Function of Utilization Maternal Child Health Book to Maternal Knowledge. Jurnal Kesehatan Masyarakat Nasional Vol. 8, No. 8.

Setyawati, L., \& Ariyanti, I. 2015. Perbedaan Penyembuhan Luka Post Partum Post Sectio Caesarea yang dilakukan Perawatan Luka dengan $\mathrm{NaCl}$ 0, 9\% dan Povidon 
Iodine $10 \%$ di RSUD Tugurejo Semarang Tahun 2013. Jurnal Kebidanan, 2(4), 1-9.

Suarni L, \& Nurjanah I. 2016. Nursing diagnosis, Nursing Outcome Classification (NOC) and Nursing Intervention Classification (NIC) in Maternity Setting. ${ }^{\text {st }}$ International conference of standardized nursing language "Bringing NANDA, NOC, NIC into action: research, education, and clinical practice. Book of Abstract.

Supardi, S., Sampurno, O. D., \& Notosiswoyo, M. 2002. Pengaruh metode ceramah dan media leaflet terhadap perilaku pengobatan sendiri yang sesuai dengan aturan. Buletin Penelitian Kesehatan, 30 (3 Sep). 